\title{
Impact of hydropeaking on hyporheic invertebrates in an Alpine stream (Trentino, Italy)
}

\author{
Maria Cristina Bruno ${ }^{1,2 *}$, Bruno Maiolini ${ }^{1}$, Mauro Carolli ${ }^{1}$ and Luana Silveri ${ }^{1}$ \\ ${ }^{1}$ Fondazione Edmund Mach, IASMA Research and Innovation Centre, Environment and Natural Resources Area, Via E. Mach 1, \\ 38010 S. Michele all'Adige (TN), Italy \\ ${ }^{2}$ Dipartimento di Scienze Ambientali, Università della Tuscia, Largo dell’Università snc, 01100 Viterbo, Italy
}

Received 5 February 2009; Accepted 28 June 2009

\begin{abstract}
The impact of repeated hydropeaking events was assessed in the Alpine stream Noce Bianco (Trentino, NE Italy). Three stations were selected, one upstream and two at $0.25 \mathrm{~km}$ and $6 \mathrm{~km}$ downstream from a hydropower plant which causes 7-fold discharge increases. We collected hyporheic invertebrates for two years. Taxa diversity and abundance were reduced in the impacted sites, especially affecting the stygobites, which were significantly less abundant at the impacted sites, whereas stygoxene invertebrates increased exponentially. Repeated hydropeaking events alter the physical-chemical characteristics of the hyporheic habitat, resulting in the recorded faunistic pattern. The deposition of the fine sediment transported by the turbinated water downstream of the power plant and the absence of natural peak floods which remove fine sediments, probably cause a reduction of the interstitial space interstitial habitat available to stygobitic taxa. Surface water natural thermal regime is altered by the hypolimnetic discharges, and such alterations propagate into the hyporheic, affecting the stenothermic taxa. Some benthic taxa used the hyporheic habitat as a refuge to avoid catastrophic drift during hydropower production operation. The main trophic roles represented in the hyporheic assemblages do not support an important role for biological interactions such as predation in determining the fine-scale patchiness of the hyporheos.
\end{abstract}

Key words: Hyporheic habitat / invertebrates / clogging / flow regime / hydropower

\section{Introduction}

The hyporheic zone is the area where surface water and ground water exchange, i.e. the sediments of many gravelor sand-bed streams below the channel and banks (Gibert et al., 1990). The hyporheic zone, being an area of intermediate biodiversity between the stream surface water and groundwater, is relatively species-rich, especially in evolutionarily ancient taxa (Boulton, 2001). Its role as a refuge for surface invertebrates has been well documented (Grimm et al., 1991; Boulton and Stanley, 1995; Brunke and Gonser, 1997). The organisms living in the hyporheic zone thus include stygoxenes (organisms that have no affinities with groundwater systems where they occur only accidentally), few stygobites (specialised subterranean forms, obligatory hypogean, mainly represented by several taxa of Crustacea) which often belong to ancient taxa and are endemic or with reduced distribution, and several stygophiles (organisms that actively exploit resources in

\footnotetext{
*Corresponding author: cristina.bruno@iasma.it
}

the ground water system for part of their life cycle as well as seek protection from unfavorable situations in the surface environment) (Marmonier et al., 1993; Gibert et al., 1994). The latter can be further divided into occasional hyporheos (mainly benthic insect larvae, the early instars of which reside in the hyporheic zone, though not necessary linked to it because individuals of the same species can also spend all their life in the surface environment); amphibite (a taxonomically variable group of stoneflies whose life cycle necessitates the use of both surface water and groundwater systems (Stanford and Gaufin, 1974)); and permanent hyporheos (several taxa of nematodes, oligochaetes, water mites, copepods, ostracods, cladocerans, and tardigrades that can spend all their life cycle either in subsurface or in surface water) (Gibert et al., 1994).

The faunistic exchange between the hyporheic and surrounding surface, groundwater, riparian, and alluvial floodplain habitats is mainly driven by hydrological exchanges (Dole-Olivier and Marmonier, 1992), which occur over a wide range of spatial and temporal scales (Boulton 
et al., 1998). The volume and rapidity of these exchanges varies greatly due to spatial changes in stream bed topography, local flow regime, and sediment permeability (Hancock, 2002), which in Alpine streams are strongly affected by hydropower plants operations. In fact, the changes in flow regime associated with sharp discharge fluctuations when water is released from the hydropower plants into the streams (hydropeaking) have cascading effects on the ecological integrity of riverine ecosystems (Bunn and Arthington, 2002). Hydropeaking modifies the specific composition and longitudinal zonation of invertebrate populations downstream of the power plant (Céréghino and Lavandier, 1998a, 1998b). While the impacts of hydropeaking on fish and benthic invertebrates have been widely investigated so far (Irvine, 1985; Moog, 1993; Céréghino and Lavandier, 1998a, 1998b; Liebig et al., 1999; Céréghino et al., 2002, 2004), impacts on the hyporheic fauna have seldom been studied. Direct impacts occur on the benthic fauna due to scouring, which removes the animals through drift (i.e. the downstream transport of aquatic organisms under the effect of current velocity) (Troelstrup and Hergenrader, 1990; Cobb et al., 1992; Boon, 1993) and indirect impacts affect the hyporheic zone through colmation of the interstitial spaces (i.e. clogging of the top layer of the channel sediments). Clogging occurs due to the reduction of flow (Baumann and Meile, 2004) and extreme flood events, and by deposition of the fine material which is usually transported by the release of hypolimnetic water (Blaschke et al., 2003; Anselmetti et al., 2007). As a consequence, available habitats for the bottom-dwelling fauna are reduced. The clogging process depends on a number of variables, such as the size distribution and concentration of the released sediments, the rate of release (gradual versus pulse releases) (Blaschke et al., 2003), the grain size distribution of the riverbed material, flow velocity, sheer stress and the hydraulic gradient (Cunningham et al., 1987; Schälchli, 1992). However, differences in hyporheic communities composition at the reach scale are not always clearly due to hydrological exchange: the hyporheic habitat is patchy at the fine scale (Dole-Olivier and Marmonier, 1992; Dole-Olivier et al., 1997) as a result of the composite responses of organisms to interstitial water velocity, sediment pore size, organic matter content, dissolved oxygen concentration, and other environmental parameters as well as biological interactions (Dole-Olivier and Marmonier, 1992; Strayer et al., 1997; Silver et al., 2002). The modification of water temperature caused by hypolimnetic discharges from thermally stratified reservoirs is considered a key threat to the integrity of lotic ecosystems and their living communities (Caissie, 2006). Such releases cause a decrease of mean annual temperature downstream of reservoirs, with significantly warmer water temperatures during winter, and cooler conditions in summer. Such alterations, although dampened, can propagate in the hyporheic zone, with effects on the hyporheic biota (Brunke and Gonser, 1997).

Besides changes in environmental conditions, biotic interactions such as competition and predation may have an important influence in biological distribution in groundwater, although such interactions in streams are still poorly studied (Strayer, 1994; Boulton, 2000; SchmidAraya and Shmid, 2000). Most of the permanent hyporheos and stigobite taxa (e.g. microturbellarians, rotifers, nematodes, small-sized oligochaetes, cladocerans and harpacticoid copepods), are filter-feeders, suspension feeders, or browsers (Schmid-Araya and Schmid, 2000) and feed on the biofilm which coats particles of various size; they are in turn prey for some benthic stygoxene, although the predatory impact is small (Schmid and Schmid-Araya, 1997). Moreover, many predacious insects in streams undergo ontogenic changes throughout their life cycle in their diet, beginning as grazers/detritivores and shifting to a carnivorous diet later in their life cycle (Anderson and Cummins, 1979), and thus the effect of predation upon the hyporheic assemblages may be only seasonal (SchmidAraya and Schmid, 2000).

The analysis of the biological (trophic habits) and ecological (affinity to groundwater habitat) traits of the species collected in the hyporheic zone can provide indications on whether predation can occur, and to detect spatial and temporal changes in response to human and natural disturbances (Claret et al., 1999). In this study we investigated the spatial (downstream from the disturbance) and temporal effects of repeated hydropeaking events on hyporheic communities along a $6 \mathrm{~km}$ reach of an Alpine stream. We focussed on the specialization level of the organisms to life in the groundwater, and aimed to assess if repeated hydropeaking events alter and reduce the habitat available to hyporheic organisms (clogging, changes in thermal regime), modifying the hyporheic invertebrate communities for several $\mathrm{km}$ downstream of the water release point, and to which extent benthic taxa use the hyporheic habitat as a refuge to avoid catastrophic drift.

\section{Material and methods}

\section{Study area and sampling stations}

The Adige River is the second-longest Italian river, draining a $12100 \mathrm{~km}^{2}$ basin and, like most large Alpine rivers, has been greatly altered by hydropower production. To date, there are 30 major reservoirs in the Adige watershed with a total capacity of $571 \times 10^{6} \mathrm{~m}^{3}$, supplying 34 hydropower plants. The study was conducted in the upper section of the Noce Bianco (Trentino, NE Italy, $46^{\circ} 24^{\prime} \mathrm{N}, 10^{\circ} 40^{\prime} \mathrm{E}$ ), a $3^{\text {rd }}$ order stream and left tributary of the Noce Stream, which in turn is a main tributary of the Adige River. The Noce Bianco is a fast-flowing $\left(1.0 \pm 0.3 \mathrm{~m} . \mathrm{s}^{-1}\right)$ gravel stream with $4-20 \mathrm{~m}$ wetted width. It is a glacial (kryal) dominated stream, fed by the Vedretta de la Mare and Careser glaciers, whose snouts are at about $2700 \mathrm{~m}$ a.s.1., with some minor non-glacial (krenal and rhithral) tributaries. The Noce Bianco watershed covers $35.9 \mathrm{~km}^{2}$. The upper Noce Bianco geological setting is dominated by unconsolidated Quaternary (Riss) scree and fluvial and glacial alluvial deposits, 


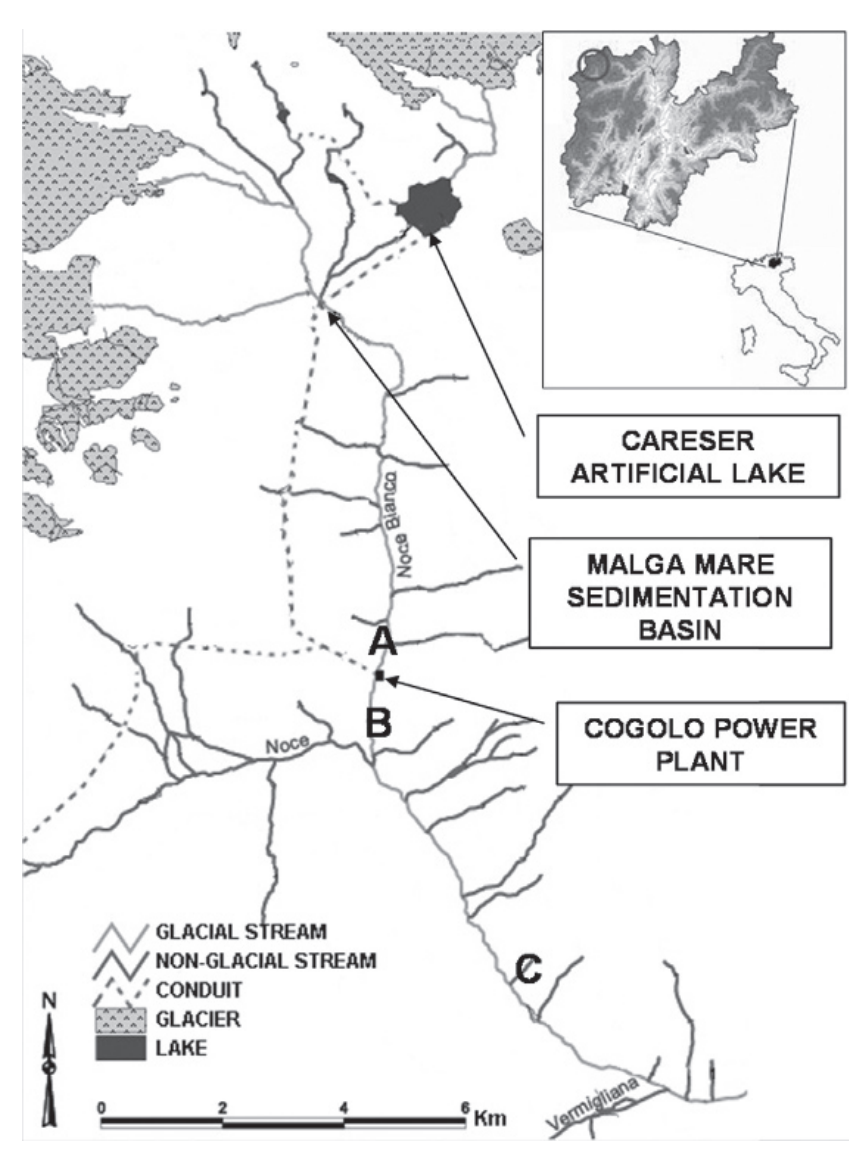

Fig. 1. Study area and location of the three sampling stations.

with a hydraulic conductivity ranging between $10^{-1}$ and $10^{-5} \mathrm{~cm} . \mathrm{s}^{-1}$ (Provincia Autonoma di Trento, 2006). The deposits mattress lies on a bedrock of metamorphic gneiss and mica-schists, and forms a porous aquifer with medium-high permeability (Autorità di Bacino dell'Adige, 2003). Thus, the hyporheic zone is a type 1 (sensu PASCALIS, 2001) i.e. it contains only advected channel water that downwells and upwells into the sediment at various spatial scales because the bedrock acts as an aquiclude beneath the river bed and is covered by a relatively thin layer of unconsolidated sediments.

The sampling stations were located upstream and downstream from the Cogolo hydroelectric power plant, which uses waters from the Careser (2603 m a.s.1.) and Pian Palù (1850 $\mathrm{m}$ a.s.1.) reservoirs. From the Careser dam water falls for $622 \mathrm{~m}$ in a penstock and reaches the Malga Mare plant (1963 $\mathrm{m}$ a.s.1.), where it is turbinated and discharged to a sedimentation basin that also collects water from the Noce Bianco stream. These waters are delivered to the Cogolo plant (1208 m a.s.l.) together with water from Pian Palù reservoir, and are finally discharged into the Noce Bianco stream (Fig. 1). When turbinated water is released into the Noce Bianco, the discharge abruptly increases from 1 to $7 \mathrm{~m}^{3} . \mathrm{s}^{-1}$ in about $10 \mathrm{~min}$ (i.e. hydropeaking), and such discharge represents the plateau that is usually kept throughout the entire phase of hydropower production, which on the Noce River usually corresponds to daily 12-h cycles (Zolezzi et al., to appear).
Three sampling stations were selected: A, located $0.25 \mathrm{~km}$ upstream from the Cogolo plant, at $1265 \mathrm{~m}$ elevation; B (1197 $\mathrm{m}$ a.s.1.) and C (1054 $\mathrm{m}$ a.s.1.) were located $0.25 \mathrm{~km}$ and $6 \mathrm{~km}$, respectively, downstream from the power plant (Fig. 1). Dominant surface grain size (sensu Cummins, 1962) was from coarse gravel to cobble with coarse sand matrix, and abundant boulders (from small to very large). In the stations downstream of the hydropower plant mobilization of the gravel riverbed did not occur, largely due to the armouring of the riverbed, a known consequence of repeated hydropeaking (e.g., Wong and Parker, 2006), and only FPOM and fine sediments were transported by the hydropeaking wave. However, bed mobilization did occur in cases of natural high flows, which exceed the increase in discharge caused by hydropeaking floods.

\section{Sampling methods}

From September 2006 to August 2008 we collected hyporheic samples monthly at the three stations, except in some winter months: November 2006, January 2007, and January 2008 when the thick snow coverage did not allow us to access safely the sampling sites. Sampling years (SY) were thus defined as first year (September 2006 to August 2007) and second year (September 2007 to August 2008).

Surface and hyporheic water temperature and conductivity were measured before sampling, and from the $10 \mathrm{~L}$ collecting bucket before filtering, respectively. We used a Hanna ${ }^{\circledR}$ HI 8730 portable conductivity and temperature meter. Conductivity was automatically corrected to the standard temperature of $20{ }^{\circ} \mathrm{C}$. Surface water turbidity was measured before sampling from November 2007 by taking three measurements with a Hanna ${ }^{\circledR}$ HI 93703 Portable Turbidity Meter and calculating the mean value.

Discharge and rainfall data were provided by the Service for Hydraulic Works of the Autonomous Province of Trento and downloaded monthly from the monitoring network website (http://soi.provincia.tn.it/dati/dati_on_ line.htm). We used the dataset from 09-01-2006 to $0 \overline{2}-29-$ 2008 from the monitoring station located on the Noce Stream at Malè, $695 \mathrm{~m}$ a.s.1., approximately $25 \mathrm{~km}$ downstream of the hydropower plant. Data from monitoring stations closer to the hydropower plant (Pellizzano, about $12 \mathrm{~km}$ downstream) were not available due to some regulation works which lasted for about two years, and which occurred during almost the entire sampling period.

Hyporheic fauna samples were collected inserting a piezometer at each station; for each sampling occasion one sample of $10 \mathrm{~L}$ of hyporheic water was collected with a Bou-Rouch pump and filtered with a plankton net (mesh size $100 \mu \mathrm{m})$. The difficulties in inserting the piezometer into the riverbed did not allow us to collect replicates. Because the substrate at the three stations was dominated by large boulders and pebbles, we were able to insert 
the piezometer to a maximum depth of about $50 \mathrm{~cm}$. Because piezometers could not be left inserted in the riverbed, due to the risk of losing them during high flows, sampling sites in the hyporheic zone where not fixed. However, great attention was posed to sample in the same reach and to select each time an area of upwelling flow. In fact, according to PASCALIS (2001), these are the areas where stygobite species are most likely to occur (represented in our sampling sites by the downstream end of riffles or gravel bars). Due to the operation schedule of the hydropower plant, samples at stations $\mathrm{B}$ and $\mathrm{C}$ were always collected while water was released from the hydropower plant (i.e. during an hydropeaking wave). After collection, biological samples were refrigerated and carried to the laboratory, where they were fixed in buffered formalin. All samples were sorted in the laboratory and organisms identified to the lowest possible taxonomical level following Campaioli et al. (1994, 1999), Fochetti et al. (2009). Many insect early instars could not be identified further than the order or family level. All copepods were sorted and counted under magnification, mounted on permanent slides, and examined with phase contrast microscopy for identification. All copepod identifications followed Dussart (1967, 1969), Stoch (1998), Karaytug (1999), Pesce and Galassi (1987). Adults and copepodites at stage $\mathrm{V}$ were identified to the species level. Individuals of earlier copepodite stages were not identified, but were labelled "copepodites", and when possible identified to the genus level; their abundances were used only when calculating the total abundances of invertebrates, but not for more detailed statistical analyses.

Each taxon was classified according to the level of ecological specialization to life in subterranean habitats sensu Gibert et al. (1994) and the trophic role was attributed, based on a review of published literature and of the information contained in the Checklist of the species of the Italian fauna (Stoch, 2000-2006). For some of the statistical analyses, taxa were grouped as follows: stygobite Harpacticoida, stygobite Cyclopoida, stygobite Syncarida, stygobite Amphipoda, stygobite Polychaeta, stygophile Harpacticoida, stygophile Cyclopoida, stygophile Plecoptera, other stygophile invertebrates (Tardigrada, Ostracoda, Baetidae), stygoxene Plecoptera, stygoxene Harpacticoida, stygoxene Cyclopoidae, other stygoxene crustaceans (Diaptomidae, Cladocera), other stygoxene invertebrates (Acarina, Nematoda, Nematomorfa, Oligochaeta, larvae of Athericidae, Ceratopogonidae, Chironomidae, Empididae, Limonidae, Psyichodidae, Simuliidae, Tipulidae, Trychoptera, Ephemeroptera Heptagenidae). Data were used to prepare a reduced faunistic matrix which was used for further analyses. We assessed for each sample the relative abundance of stygoxene by calculating the $\mathrm{R}$ index (Di Lorenzo et al., 2003) as: $\mathrm{R}=\sum_{i} p_{i} /\left(\sum_{z} p_{z}+\sum_{x} p_{x}\right)$ with $p_{i}=\mathrm{n}$. individuals of the stygoxene taxon " $i$ " and $i=1, \ldots, n ; p_{z}=\mathrm{n}$. individuals of the stygobite taxon " $z$ " and $z=1, \ldots, m$; $p_{x}=\mathrm{n}$. individuals of the stygophile taxon " $x$ " and $x=1, \ldots, q$.

\section{Statistical analysis}

Differences in the mean among stations of conductivity and temperature of surface and hyporheic water were tested with a one way ANOVA (factor: station). The variables which significantly differed were tested with a Student's $t$ test for differences between pairs of stations. Temporal differences in the mean were tested on bimonthly data (i.e. October, December, February, April, June, and August): differences for the variables among months between the two years, and among months between stations were tested by running two repeatedmeasures ANOVA analyses (between-subjects factor: year and station, respectively; within-subject factor: month). We run a Tukey HSD post hoc test in order to identify which means contributed to the effect; i.e. which groups were particularly different from each other.

The extended faunistic matrix, with a total of 63 samples ( 21 for each station) and 55 taxa was used to calculate the Shannon-Wiener Diversity Index, calculated as $\mathrm{H}^{\prime}=-\Sigma p_{i^{*}} \ln p_{i}$, where $p_{i}$ is the proportion of the sample represented by species $i$ (Pielou, 1969), and $\ln$ is the natural logarithm, and the estimated species richness by rarefying the samples to the smallest sample size (Sanders, 1968). Differences in the mean distribution among stations or between years for each taxon were tested with a MannWithney non-parametric test.

The reduced matrix (14 taxa, because the unidentified copepods were excluded from the analysis) was first transformed in $\log (x+1)$ and a resemblance matrix was calculated using the Bray-Curtis Similarity Index. We performed two separate Analysis of Similarities (ANOSIM) analyses (Clarke, 1993) testing the null hypothesis that there are no assemblage differences: among stations (oneway ANOSIM, factor: station); among stations over time (nested two-way ANOSIM analysis, factor "month" nested within "station").

We investigated the causes of the significant differences in species assemblages by running: (1) an Indicator Species Analysis (Dufrêne and Legendre, 1997) which detects and describes the value of different species for indicating differences in sample units. The Indicator Species Analysis (ISA) produces indicator values (IV) for each species in each group, which are tested for statistical significance as indicators using a Monte Carlo randomization; (2) a Detrended Correspondence Analysis (DCA) (Hill and Gauch, 1980) to ordinate both faunistic groups and samples simultaneously. All analyses were performed using Primer 6 ver. 6.1.6 (PRIMER-E Ltd, 2006), Statistica ver. 8.1 (StatSoft Inc., 2008), PC-ORD for Windows ver. 4.20 (McCune and Mefford, 1999).

\section{Results}

The water released from Cogolo-Pont hydropower plant causes sudden changes in discharge in the Noce Stream (hydropeaking) almost on a daily basis (Fig. 2). Such variations are overimposed on the natural variations 


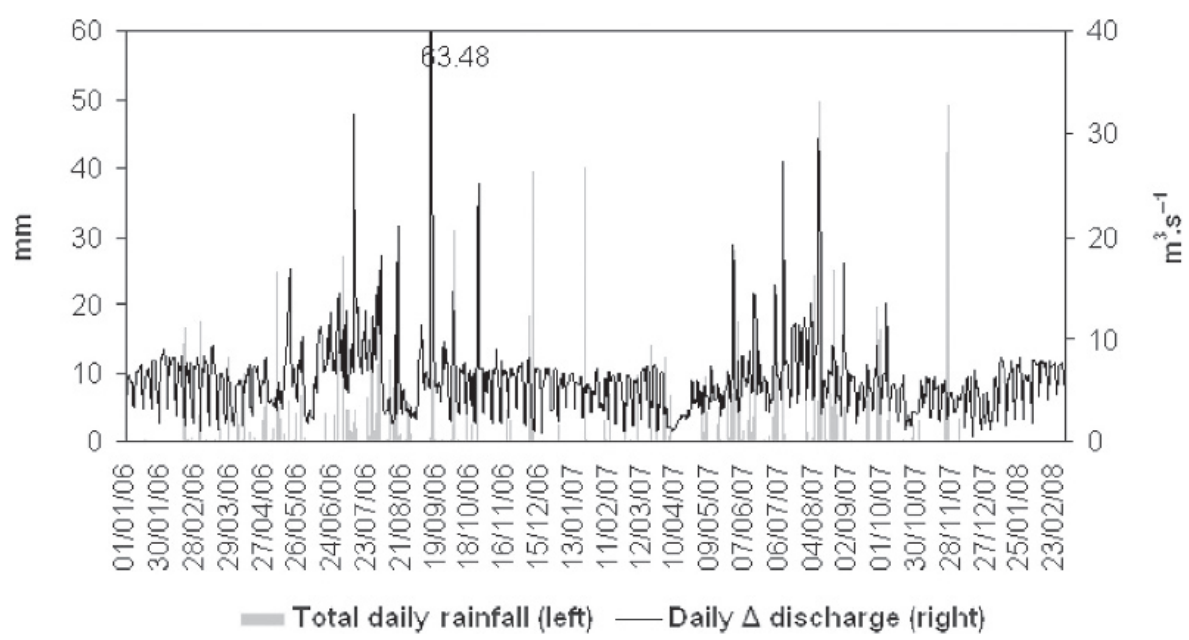

Fig. 2. Total daily rainfall (left) and difference between maximum and minimum daily discharge value (right) measured from 09-012006 to 02-29-2008 at Malè monitoring station, on the Noce Stream, about $25 \mathrm{~km}$ downstream of Cogolo-Pont hydropower plant.

caused by rainfall, and propagate for long distance downstream (Fig. 2). When Cogolo-Pont hydropower station is operating at the maximum turbine capacity, discharge of the Noce Bianco Stream at station B can increase from 1 to $7 \mathrm{~m}^{3} \cdot \mathrm{s}^{-1}$ within approximately $10 \mathrm{~min}$. The analysis of a long-term daily discharge data $25 \mathrm{~km}$ downstream of the plant, where the effects of rainfall and of the immission of tributaries with natural alpine flow regime are also present, show daily oscillations due to hydropeaking (Fig. 2) with a mean value calculated over the entire period of about $6 \mathrm{~m}^{3} \cdot \mathrm{s}^{-1}$ and with 378 days out of the 793 in the database with a daily increase higher than $6 \mathrm{~m}^{3} . \mathrm{s}^{-1}$.

\section{Physical-chemical variables}

Physical-chemical characteristic of surface and hyporheic water differed between upstream and downstream stations, and with increasing distance downstream for the hydropower plant. Temporal variations of surface water propagated to the hyporheic water, albeit slightly attenuated. In fact, surface water was as average $0.53,1.34$, and $0.49{ }^{\circ} \mathrm{C}$ colder than hyporheic water at $\mathrm{A}, \mathrm{B}$, and $\mathrm{C}$, respectively, and conductivity as average 8,8 , and $4 \mu \mathrm{S} . \mathrm{cm}^{-1}$ lower.

Only surface water conductivity (SWC) and hyporheic water conductivity (HWC) differed significantly among stations (One-Way ANOVA $p=0.0016$ and $p=0.0029$, respectively); these overall differences were due to the difference between $\mathrm{A}$ and $\mathrm{B}$ and between $\mathrm{A}$ and $\mathrm{C}$ for SWC (Student's $t$ tests $p=0.003$ and $p=0.005$, respectively), and between $\mathrm{A}$ and $\mathrm{C}$ for HWC (Student's $t$ tests $p=$ 0.001151). In fact for both surface and hyporheic water conductivity was lower upstream of the hydropower plant, and increased downstream where higher extreme values were reached (Fig. 3).

Water temperatures varied seasonally as expected in an Alpine stream, with high values from late spring to early autumn, maxima in June-July and minima in December-

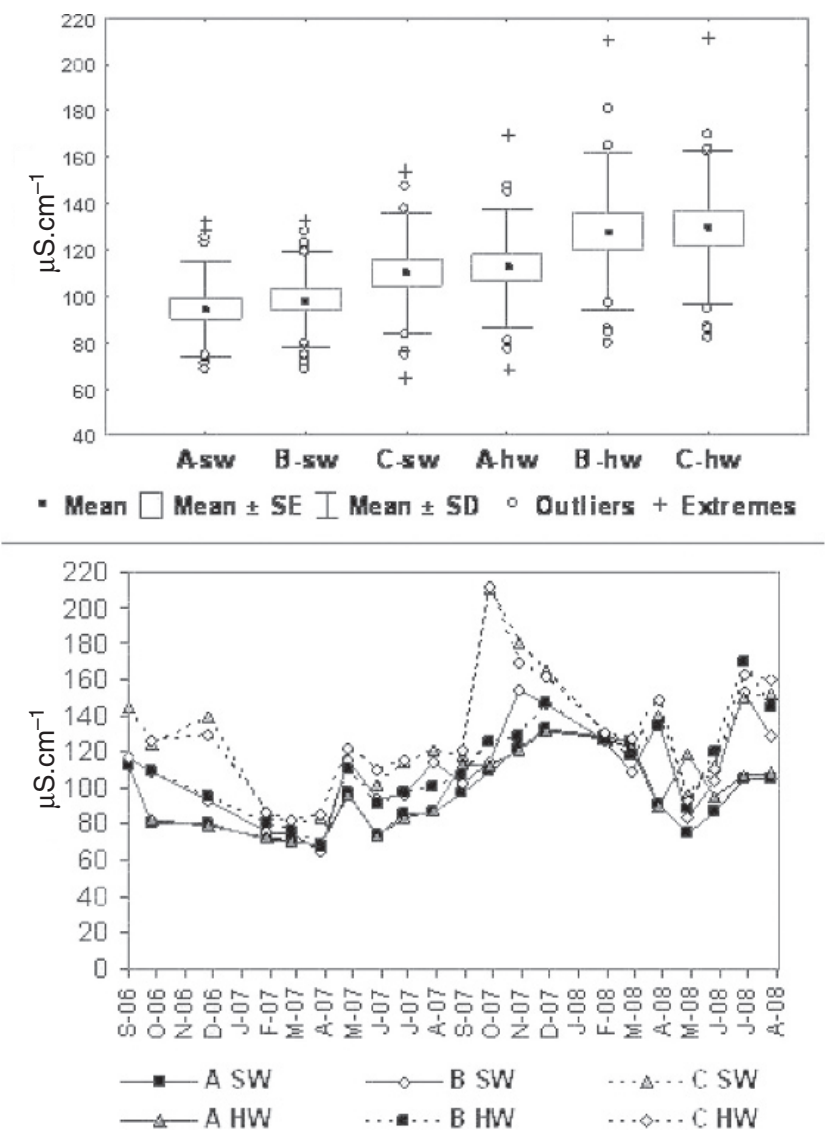

Fig. 3. Top: Box-whiskers plots of surface (SW) and hyporheic (HW) water conductivity at each of the sampling stations. Bottom: Temporal trends of surface (SW) and hyporheic (HW) water conductivity at each station.

February. However, this trend was clearly detectable at A, the unimpacted station (Fig. 4), whereas in the impacted stations a thermal alteration is overimposed to the natural temperature variations: temperatures were lower in spring-summer, and higher in autumn-winter (Fig. 4). 

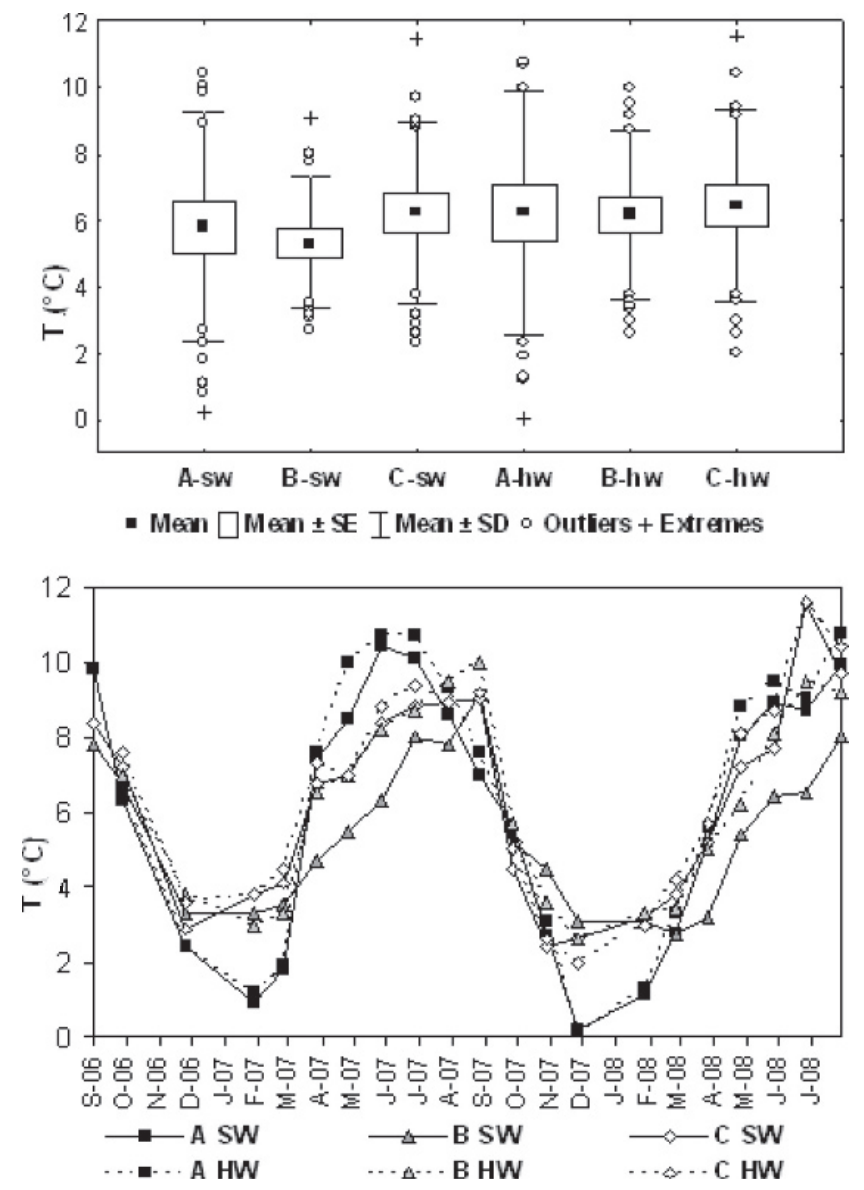

Fig. 4. Top: Box-whiskers plots of surface (SW) and hyporheic (HW) water temperature at each of the sampling stations. Bottom: Temporal trends of surface (SW) and hyporheic (HW) water temperature at each station.

At the impacted stations temperatures were less variable (more so at the station immediately downstream, B); the extreme high values were lower, and the extreme low values higher than at the non-impacted station (Fig. 4). The thermal alterations propagated to the hyporheic water, whose trends follow those of surface water (Fig. 4).

When assessing the differences over time, only hyporheic water temperature (HWT) showed a significant year effect, all the variables differed over time between the two years and among the three stations (repeated-measures ANOVA, $p<0.05$ ), but none had a significant month $\times$ year interaction $(p>0.005)$, and only surface water temperature $(\mathrm{SWT})$ showed a significant month $\times$ station interaction $(p<0.05)$ (Table 1$)$. These were due to significant differences between the unimpacted station A (Tukey test $p<0.05)$ and both the impacted stations during all months except the winter ones (December and February), i.e. for all the months when turbinated water was released by the hydropower plant.

Turbidity (measured in NTU) was increasingly higher and more variable downstream of the hydropower plant (Fig. 5), being 1.8 times higher at B and 3.6 times higher at $\mathrm{C}$ than at $\mathrm{A}$, respectively.

\section{Biotic variables}

A total of 4055 invertebrates were collected, for a mean of 5724,4262 , and 9785 ind. $\mathrm{m}^{-3}$ at $\mathrm{A}, \mathrm{B}$, and $\mathrm{C}$ respectively (Table 2, Online Material, available at http://www.limnology-journal.org); the abundance of each taxon and by groups based on taxonomic affinity and specialization level are shown in Tables 2 and 3, respectively. Most Plecoptera and all Baetidae were represented by early larval stages, which are typically stygophile (Williams, 1984; Lock and Goethals, 2008). Shannon-Wiener diversity index and the estimated species richness were lower at the impacted stations and they decreased downstream, although a stronger trend was present only for the latter (Fig. 6). Almost all the stygophile and stygoxene taxa collected in the hyporheic samples in this study were not predators (Table 2, Online Material). In fact, Insecta larvae were represented by stages which are typically shredder-detritivore and/or collector-gatherers (Plecoptera, Ephemeroptera, Trichoptera, and Diptera), and filter-feeders (Diptera Simuliidae); Crustacea were filter-feeders (Cladocera, Ostracoda) or gatherers (Copepoda, some Ostracoda), and other Arthropoda were detritivores (Oligochaeta, Nematoda). The only predators could have been represented by some larvae of Insecta, e.g. for some taxa of Limonidae, Athericidae, Ceratopogonidae, Empididae. However, the identification level for these groups was not detailed enough to determine if the taxa collected belonged to the predator feeding group.

The total abundance of all stygobite, stygophile and stygoxene taxa collected in each station is shown in Figure 7. Stygobite taxa were more abundant at A and decreased exponentially with distance from the release point whereas stygoxene taxa followed an opposite trend. Stygophiles decreased only at $\mathrm{B}$. The mean value of the $\mathrm{R}$ index was higher at the impacted stations and increased downstream: 0.63 at $\mathrm{A}, 1.88$ at $\mathrm{B}$, and 7.33 at $\mathrm{C}$.

The composition of the hyporheic invertebrate assemblages changed significantly with distance from the turbinated water release, i.e. among stations (one-way ANOSIM, factor STATION: $p=0.002, \mathrm{R}=0.125$ ) and between the three stations over time (nested two-way ANOSIM $p=0.001, R=0.494$ ). The ISA detected the species that indicate differences between stations; the results are listed in Table 3 and indicate that stygobite Cyclopoida, Syncarida and Polychaeta, stygophile Plecoptera and stygoxene Cyclopoida and other invertebrates were significant indicators. In particular, station A was characterized by the rare stygobite Syncarida and by the abundant stygobite Polychaeta and stygophile Plecoptera; B was characterized by the abundant stygobite Cyclopoida and $\mathrm{C}$ by the abundant stygoxene Cyclopoida and other invertebrates, among them Nematoda, Nematomorpha and Oligochaeta were the most abundant (Table 2, Online Material).

Some taxa in particular showed relevant differences among stations (Table 2, Online Material) and between 
Table 1. Repeated-measures ANOVA for environmental variables in the three sampled stations. Underscored numbers represent significant differences.

\begin{tabular}{|c|c|c|c|c|c|c|c|c|c|c|c|}
\hline \multirow{3}{*}{ 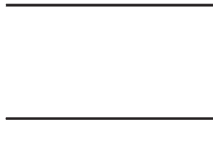 } & \multirow{2}{*}{$\mathrm{df}$} & \multicolumn{2}{|c|}{ Between subjects } & \multicolumn{3}{|c|}{ Within-subjects } & \multicolumn{2}{|c|}{ Between subjects } & \multicolumn{3}{|c|}{ Within-subjects } \\
\hline & & Year & Error & Month & $\begin{array}{c}\text { Month } \times \\
\text { year }\end{array}$ & Error & Station & Error & Month & $\begin{array}{l}\text { Month } \times \\
\text { station }\end{array}$ & Error \\
\hline & & 1.000 & 4.000 & 5.000 & 5.000 & 20.000 & 2.000 & 3.000 & 5.000 & 10.000 & 15.000 \\
\hline \multirow{4}{*}{$\begin{array}{l}\text { Temperature } \\
\text { surface water }\end{array}$} & SS & 4.988 & 4.161 & 6.752 & 6.752 & 30.739 & 3.961 & 5.188 & 213.812 & 27.419 & 10.072 \\
\hline & MS & 4.988 & 1.040 & 42.762 & 27.823 & 1.537 & 1.980 & 0.729 & 42.762 & 2.742 & 0.671 \\
\hline & $\mathrm{F}$ & 4.795 & & 27.823 & 0.879 & & 1.145 & & 63.687 & 4.084 & \\
\hline & $\mathrm{p}$ & 0.094 & & $<\underline{0.001}$ & 0.513 & & 0.427 & & $<\underline{0.001}$ & $\underline{0.007}$ & \\
\hline \multirow{4}{*}{$\begin{array}{l}\text { Temperature } \\
\text { hyporheic } \\
\text { water }\end{array}$} & SS & 6.378 & 1.293 & 288.344 & 7.612 & 16.677 & 1.150 & 6.522 & 288.344 & 14.267 & 10.022 \\
\hline & MS & 6.378 & 0.323 & 57.669 & 1.522 & 0.834 & 0.575 & 2.174 & 57.669 & 1.427 & 0.668 \\
\hline & $\mathrm{F}$ & 19.726 & & 69.160 & 1.826 & & 0.265 & & 86.317 & 2.153 & \\
\hline & $\mathrm{p}$ & $\underline{0.011}$ & & $<\underline{0.001}$ & 0.153 & & 0.784 & & $<\underline{0.001}$ & 0.089 & \\
\hline \multirow{4}{*}{$\begin{array}{l}\text { Conductivity } \\
\text { surface water }\end{array}$} & SS & $1191 \overline{1.900}$ & 8993.400 & 5655.100 & 2057.400 & 5489.800 & 8513.300 & 12092.000 & 5655.100 & 2923.800 & 4623.500 \\
\hline & MS & 11911.900 & 2173.400 & 1121.000 & 411.500 & 274.500 & 4256.700 & 4030.700 & 1131.000 & 292.400 & 308.200 \\
\hline & $\mathrm{F}$ & 5.481 & & 4.120 & 1.499 & & 1.056 & & 3.669 & 0.949 & \\
\hline & $\mathrm{p}$ & 0.079 & & $\underline{0.010}$ & 0.235 & & 0.450 & & $\underline{0.023}$ & 0.520 & \\
\hline \multirow{4}{*}{$\begin{array}{l}\text { Conductivity } \\
\text { hyporheic } \\
\text { water }\end{array}$} & SS & 14044.600 & 8857.900 & 4981.600 & 1205.500 & 4935.500 & 8694.400 & 14206.100 & 4981.600 & 2628.100 & 3512.800 \\
\hline & MS & 14044.600 & 2214.500 & 996.300 & 241.100 & 246.800 & 4348.200 & 4735.400 & 996.300 & 262.800 & 234.200 \\
\hline & $\mathrm{F}$ & 6.342 & & 4.037 & 0.977 & & 0.918 & & 4.254 & 1.222 & \\
\hline & $\mathrm{p}$ & 0.065 & & 0.011 & 0.456 & & 0.489 & & 0.013 & 0.407 & \\
\hline
\end{tabular}

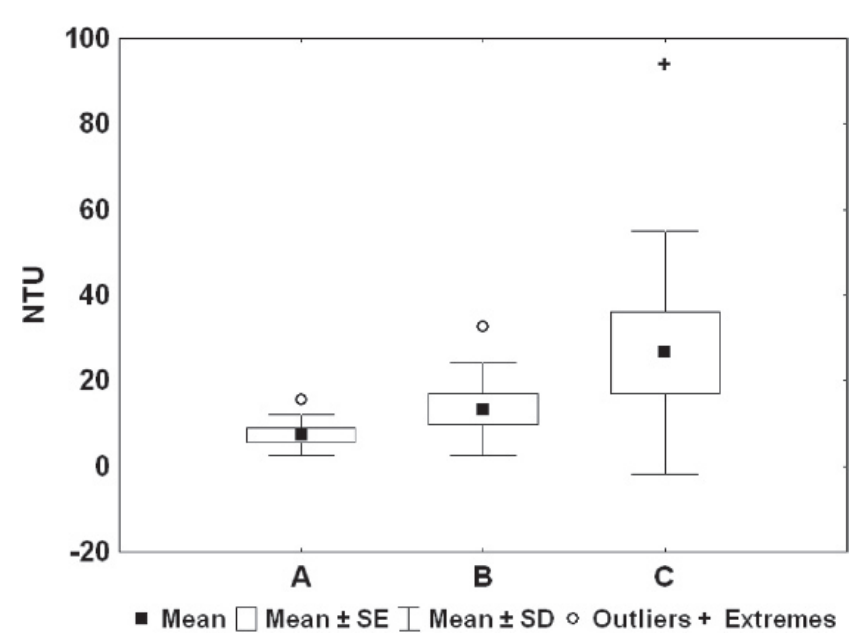

Fig. 5. Box-whiskers plots of surface water turbidity at each of the sampling stations.

years which need to be discussed in detail. For the stygobite taxa, the distribution of the extremely specialized interstitial species which exclusively dwell in the sediment interstices (i.e., Parastenocaris sp., Graeteriella unisetigera and, among non-Copepoda, Bathynella sp. and Troglochaetus beranecki) differed significantly $(p>0.05$, Mann-Withney test) among stations. The first two species were more abundant at B, Parastenocaris sp. predominantly present in autumn-winter months and in the first sampling year. The remaining two species were exclusive (Bathynella) or almost exclusive (T. beranecki) of station A, the former in July-October only of the first year, the latter more abundant in September-March of the first year. All the specimens of the stygophile Paracyclops imminutus were collected in May 2008 at A. Among the stygoxene taxa, Trichoptera were more abundant at B, however this datum is strongly biased because $93 \%$ of the specimens of that station were collected in one occasion, in October 2007. Similarly, the strong dominance of Nematoda at $\mathrm{C}$ is due to the collection of $69 \%$ of the specimens of that station in April 2007 and other 13\% on March 2008. Oligochaeta were more abundant at C, and especially in May-July. Chironomidae were the most abundant taxon for Insecta; they decreased in abundance from $\mathrm{A}$, to $\mathrm{B}$, to $\mathrm{C}$.

The average abundance of individuals collected for the two sampling years (SY) differed (Table 2, Online Material): in the first SY it was about $1 / 2$ of the value of the second SY (from a mean density per month of 8472 to 4839 ind $\mathrm{m}^{-3}$ (Table 2, Online Material). Among the dominant taxa (those representing $90 \%$ of the total density), the relevant differences were due to two stygoxene taxa, Chironomidae, which were about twice more abundant in the first SY, Nematoda which were three times more abundant, and among the stygobites, Parastenocaris sp. and $T$. beraneck $i$ were 25 and six time more abundant the first year, respectively. The values for the two sampling years were similar at A, they decreased to almost $1 / 2$ from the first SY to the second SY at B and C. The most abundant stygoxene taxa decreased at the impacted stations (Chironomidae and Oligochaeta at B, Nematoda at $\mathrm{C}$ ), and the most abundant stygobite decreased at station A (Bathynella sp. decreased 2.6 times, Troglochaetus beranecki 6.3 times), at stations $\mathrm{A}$ and $\mathrm{B}$ (Parastenocaris cf glacialis decreased from 230 to 0 ind. $\mathrm{m}^{-3}$ at $\mathrm{A}$, and 23.1 times at $\mathrm{B}$ ) at stations $\mathrm{B}$ and $\mathrm{C}$ while increasing at $\mathrm{A}$ (Diacyclops cf maisi increased 4.5 times at $\mathrm{A}$, decreased 5.6 and 1.2 times at $\mathrm{B}$ and $\mathrm{C}$ respectively).

Samples and taxa were ordered in the joint plot resulting from the DCA for axis 1 and 2 (which together 
Table 3. Mean densities (expressed as ind. $\mathrm{m}^{-3}$ ) per each station of invertebrates, grouped for main taxonomic group and specialization level, and results of Indicator Species Analysis (IV value and station where such value was recorded; value of the Monte Carlo test of significance of the observed maximum indicator value for each taxon). Significant IV values marked with asterisk, corresponding taxa underlined.

\begin{tabular}{lcccccc}
\hline & $\begin{array}{c}\text { Total } \\
\text { density A }\end{array}$ & $\begin{array}{c}\text { Total } \\
\text { density B }\end{array}$ & $\begin{array}{c}\text { Total } \\
\text { density C }\end{array}$ & $\begin{array}{c}\text { Station with } \\
\text { maximum IV }\end{array}$ & $\begin{array}{c}p \\
\text { IV value }\end{array}$ & $\begin{array}{c}p \\
\text { (Monte Carlo test) }\end{array}$ \\
\hline Harpacticoida, stygobite & 110 & 314 & 20 & $\mathrm{~B}$ & 19 & 0.1800 \\
Cyclopoida, stygobite & 776 & 838 & 205 & $\mathrm{~B}$ & 38 & $0.0310^{*}$ \\
Syncarida, stygobite & 95 & 0 & 0 & $\mathrm{~A}$ & 24 & $0.0090^{*}$ \\
Amphipoda, stygobite & 0 & 0 & 10 & $\mathrm{C}$ & 5 & 0.3110 \\
Polychaeta, stygobite & 1410 & 24 & 10 & $\mathrm{~A}$ & 37 & $0.0010^{*}$ \\
Cyclopoida, stygophile & 129 & 0 & 0 & $\mathrm{~A}$ & 5 & 1.0000 \\
Harpacticoida, stygophile & 57 & 76 & 125 & $\mathrm{~B}$ & 13 & 0.9590 \\
Plecoptera, stygophile & 305 & 90 & 85 & $\mathrm{~A}$ & 36 & $0.0130^{*}$ \\
Other invertebrates, stygophile & 548 & 114 & 705 & $\mathrm{C}$ & 27 & 0.4820 \\
$\quad$ Tardigrada, Ostracoda, Baetidae) & & & & $\mathrm{A}$ & 21 & 0.0500 \\
Plecoptera, stygoxene & 67 & 0 & 75 & $\mathrm{C}$ & 20 & 0.4780 \\
Harpacticoida, stygoxene & 67 & 57 & 175 & $\mathrm{C}$ & 13 & 0.0590 \\
Cyclopoida, stygoxene & 0 & 14 & 335 & $\mathrm{~B}$ & 9 & 1.0000 \\
Other crustacean, stygoxene & 10 & 29 & 30 & $\mathrm{C}$ & 40 & $0.0400^{*}$ \\
Other invertebrates, stygoxene & 2024 & 2633 & 7890 & $\mathrm{~A}$ & 15 & 0.8430 \\
Copepoda, unknown & 138 & 95 & 145 & & \\
\hline
\end{tabular}

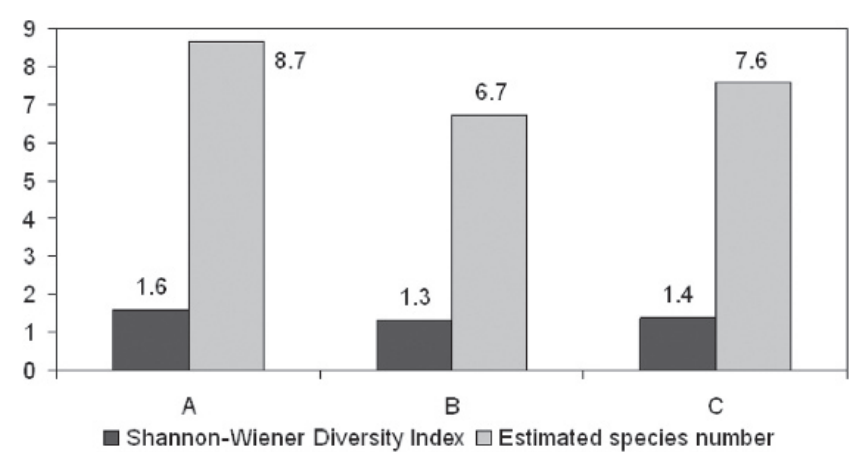

Fig. 6. Shannon-Wiener Diversity Index and estimated species number for each of the sampling stations.

accounted for $60.4 \%$ of the correlation between ordination distances and distances in the original $n$-dimensional space) (Fig. 8). The vectors representing the indicator species according to the Indicator Species Analysis identify on axis 1 a gradient of stygobite taxa which characterize most of the samples collected at station A, opposed to most of the stygoxene and stygophile taxa which were collected at the downstream-most station (C).

\section{Discussion}

Changes in flow regime associated with hydropeaking are known to decrease both the density and biomass of benthic invertebrates downstream from hydropower plant outlets (Irvine, 1985; Moog, 1993; Céréghino and Lavandier 1998a, 1998b; Céréghino et al., 2002, 2004) by increasing the intensity of bed scour (Brittain and Eikeland, 1988; Gore et al., 1994), which in turn leads to a high catastrophic drift (Crisp and Robson, 1979; Gore

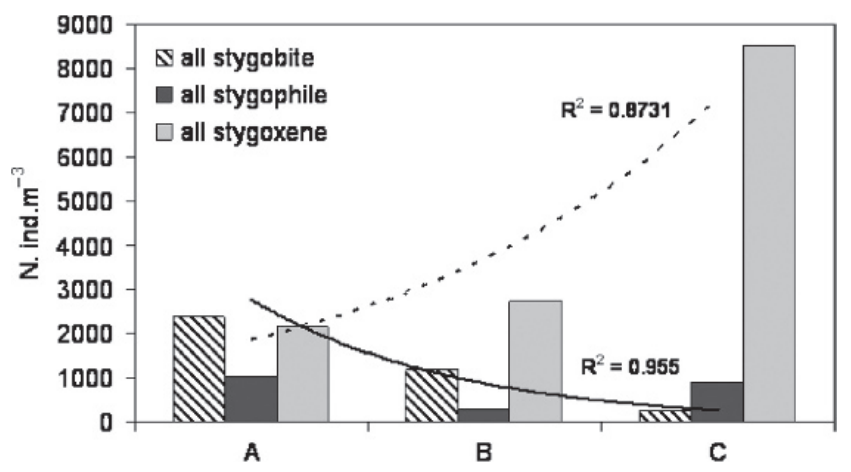

Fig. 7. Total abundance of stygobite, stygophile and stygoxene taxa collected at each station, exponential trendline and $R^{2}$ value for stygobite (continuous line) and stygoxene (dotted line) taxa.

et al., 1989); and by clogging of the river bed because of deposition of the fine material transported by released water (Blaschke et al., 2003; Anselmetti et al., 2007), which reduces the available habitat for the bottom-dwelling fauna. As a consequence, the specific composition and longitudinal zonation of invertebrate populations below the outlet is altered (Céréghino and Lavandier, 1998a, 1998b). The effects propagate on the hyporheic zone, because water flow and substrate structure are the main factors influencing the small-scale spatial distribution of hyporheic fauna (e.g. Robertson et al., 1995; Maridet et al., 1996; Palmer et al., 1996). In this specific case study, the daily cycles of hydropeaking caused by the operation of Cogolo-Pont hydropower plant altered the hydrological (discharge), physical (temperature), and chemical (conductivity, suspended sediment) regimes of the Noce Stream (Bruno et al., 2008; Carolli et al., 2009; Siviglia et al., 2009; Zolezzi et al., to appear). Such alterations increase the instability of the benthic and hyporheic habitats, which 


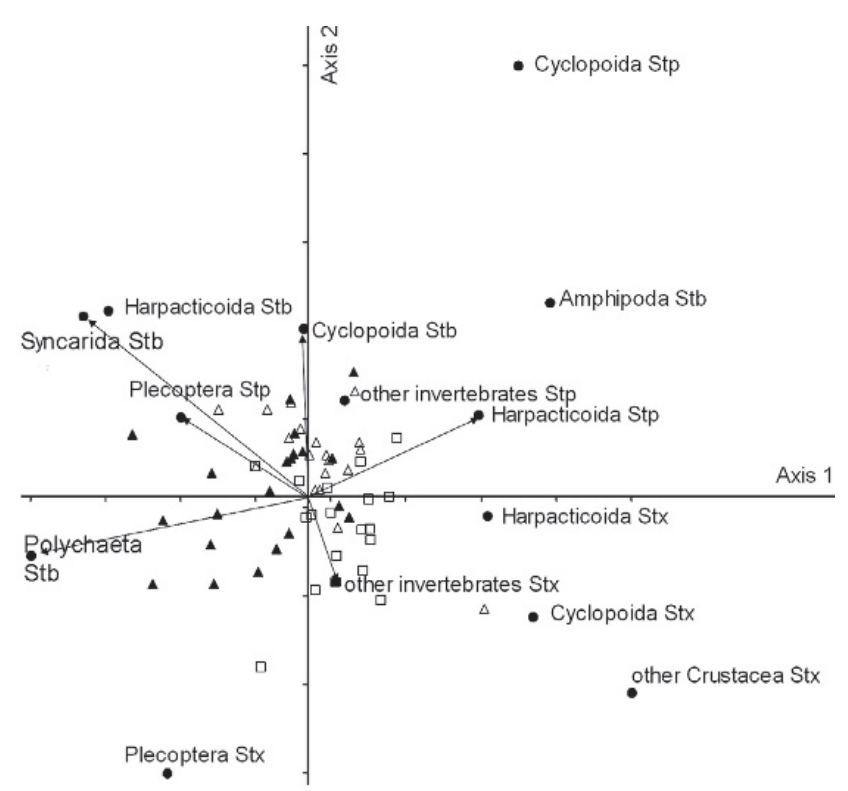

Fig. 8. Detrended Correspondence Analysis. Joint plot of samples and taxa. Vectors represent the indicator species according to the Indicator Species Analysis. Black triangles: station $\mathrm{A}$; white triangles: station $\mathrm{B}$; white squares: station $\mathrm{C}$; black circles: taxa.

results in changes in the composition of hyporheic assemblages through the reduction of abundance and diversity of stygobite taxa (because the suitable habitat for these specialized taxa is reduced), and increase of abundance and diversity of benthic invertebrates (i.e. stygoxenes, which actively enter the hyporheic to find a refuge from the stress imposed to the benthic habitat).

Daily peaks of discharge affect mostly the benthic invertebrates, because they cause an increase in catastrophic drift, which is usually associated with flood conditions during which the substrate is physically disturbed, but which can also occur in the absence of sediment movement with effects not less dramatic for benthic communities than those of catastrophic floods (Imbert and Perry, 2000; Gibbins et al., 2007a, 2007b). The impacts on one hydropeaking wave on benthic invertebrates in the Noce Bianco were assessed in a previous study (unpublished data), and consisted of inducing a quick drift within 5-10 min from the beginning of the hydropeaking wave; larger-sized individuals were more easily removed, and the highest drift rate was recorded at the station immediately downstream of the water releases (B), where scouring due to hydropeaking was stronger, and the possibility to find a refuge in the hyporheic zone was hindered by the sudden discharge increases. Changes in flow are well known to influence meiofaunal movements and distribution: invertebrates tend to aggregate in areas of the streambed characterized by lower shear stress (Robertson et al., 1995, 1997). Hyporheic substrate particles provide firm attachment and low-flow microhabitats, and thus can provide refuge against strong sheer stress during high-discharge events, extreme temperature, and bedload movements
(Ward, 1992; Dole-Olivier et al., 1997; Lancaster and Belyea, 1997; Townsend et al., 1997). In high altitude streams with strong bedload movement, the benthic community has been reported to persist in the hyporheic interstitial (Schwoerbel, 1962), which functions as a reservoir able to colonize depleted benthic habitats (Townsend and Hildrew, 1994). The hyporheic zone acts as a patchy refuge, depending on hydrology (upwelling or downwelling) and substratum stability and amplitude of changes in discharge; in the case of spates, the principal hyporheic refuges for benthic taxa corresponds to upwelling areas (Dole-Olivier et al., 1997). The importance of the hyporheic zone as a refuge for benthic invertebrates is greater in frequently disturbed sites, but decreases in importance in stable systems (Fowler and Death, 2001). Important migrations of benthic groups or hyporheic taxa (e.g. Cyclopoida and Harpacticoida) were observed deep into the sediment $(2 \mathrm{~m})$ of a by-passed section of the Rhône River (Dole-Olivier et al., 1997), and such movements were very important at low (discharge increase of 2-10-fold) and medium (10-37-fold) magnitude spates, but were unimportant at high discharge ( $>37$-fold), when the substratum became mobile and induced drift of benthic organisms. The discharge variations induced by hydropeaking in the study area (7-fold) can be compared to low magnitude spates and benthic taxa did increase as abundance of taxa and individuals in the shallow hyporheic zone of the hydropower-impacted stations.

Disturbance is not only caused by variations in discharge: other physical-chemical variables are important in structuring the benthic/hyporheic faunal exchanges, such as temperature and sediment transport and deposition. Changes of temperature downstream of hydropower water releases are well-documented (Preece and Jones, 2002; Wüest et al., 2002; Jakob et al., 2003; Caissie, 2006; Anselmetti et al., 2007), and they are considered a key threat to the integrity of lotic ecosystems and their living communities (Caissie, 2006). The impact of hydropeaking on the downstream temperature regime was monitored during 2007 in the Noce River system (Carolli et al., 2009); the reaches impacted by hydropeaking showed minor annual temperature ranges, with lower temperatures recorded during summer and higher temperatures during winter. Such variations are confirmed by this study and are shown to propagate to the hyporheic zone, although slightly attenuated, as already demonstrated in several studies in Alpine and other rivers (e.g. Brunke and Gonser, 1997; Dole-Olivier, 1998; Fowler and Scarsbrook, 2002). The thermal alterations related to the hydropeaking waves probably affect the composition of hyporheic assemblages in the Noce Stream. In fact, the hyporheic zone may provide a temperature refuge for epigean taxa (Boulton et al., 1998), and high surface water temperature may initiate the movement of some taxa into the hyporheic zone (Fowler and Scarsbrook, 2002). On the other hand, because in natural conditions, hyporheic temperatures are cooler in summer and warmer in winter relative to the water in the channel and less variable (Williams, 1984; Ward, 1994; Dole-Olivier, 1998), the imposed variation 
to the hyporheic thermal regime might limit the distribution of stygobite taxa.

The increased conductivity and turbidity recorded at the impacted stations are due to the effects of hypolimnetic releases from reservoirs which act as sediment and chemical traps (Humborg et al., 2000; Loizeau and Dominik, 2000; Friedl et al., 2004; Anselmetti et al., 2007; Jaun et al., 2007), and the suspended material transported by the flow is eventually deposited, causing colmation (i.e. clogging of the top layer of the channel sediments; Brunke and Gonser, 1997). The requirements for clogging to occur are low flow conditions, suspended particles and fine bedload, and higher concentration of such material can accelerate the temporal development of colmation (Diplas and Parker, 1992; Brunke, 1999). The oscillating floods caused by hydropower operation are often not powerful enough to compensate the lack of natural flood events in order to remove the clogging of the riverbed (Baumann and Meile, 2004; Fette et al., 2007). On the Noce Stream the water velocity reaches a maximum value of $1 \mathrm{~m} . \mathrm{s}^{-1}$ during hydropeaks, which removes only the fine sediment from the first few $\mathrm{cm}$ of sediment, and possibly leaves a deeper clogged layer (Blaschke et al., 2003). The presence of a clogged layer, although not measured directly, is suggested by the presence of suspended particles and fines downstream of the hydropower plant, as measured by the high turbidity and conductivity recorded there, and by the decrease in hyporheic diversity in the impacted sites, especially affecting the stygobites, i.e. those organisms which are strictly related to the availability of interstitial space. Other studies (Gayraud and Philippe, 2001) provided direct evidence that the amount of interstitial space has a selective effect on invertebrates through their morphological traits, and invertebrates which are small, cylindrical or spherical, and with a highly flexible body are selected in streams with clogged interstitial space. In fact, in our study the most abundant taxa at each station can be related to pores size: whereas at $\mathrm{A}$ the most abundant stygobites were larger crustaceans (Bathynella sp.), or small vermiform invertebrates ( $T$. beranecki) which require larger pore space, smaller, cylindrical crustaceans were dominant at B (Parastenocaris sp. which is about $0.37 \mathrm{~mm}$ long, and Graeteriella unisetigera, which is $0.5 \mathrm{~mm}$ long), and stygobite taxa were very rare at C. In contrast, the use of the hyporheic as a refuge by epigean fauna (stygoxene) increased downstream of the hydropower plant: benthic invertebrates have been reported to penetrate into the hyporheic more deeply than usual during floods (Williams and Hynes, 1974; Marchant, 1988), but sediment can act as a shelter only if enough space (porosity) is available (Maridet et al., 1996). In our study Nematoda and Oligochaeta were among the most abundant stygoxene taxa collected in the hyporheic; these taxa have flexible bodies and thus are able to penetrate into the fine sediment, and thus move through the interstices even if these are clogged. Nematoda are known to be abundant in polluted habitats (e.g. Zullini, 1976; Picazo and Ocana, 1991), and the peaks in abundance recorded for such taxa might correspond to pulses of organic matter from upstream farms and settlements. Increased sedimentation has been reported to cause an overall decline in stygoxene abundance, but it also causes an increase in fine particle detritivores at the expense of carnivores and herbivores, and relative decline in macrofauna and highly mobile taxa as interstitial space fills (Claret et al., 1999). Bo et al. (2007) showed with experimental manipulations that the most clogged substrates provide always the poorest interstitial habitat quality for benthic invertebrates, in particular the abundance of filterers is strongly reduced and only few groups, such as Oligochaeta, benefited from the clogging process. Chironomidae were very abundant in the hyporheic but decreased in the impacted stations; although Chironomidae have a cylindrical body, which would help them to move within the interstices, they have been reported to have low ability in migrating within the sediment under hydraulic stress (Palmer et al., 1992; Gayraud et al., 2000). Such low ability to find shelter in the sediment, and the consequent higher susceptibility to be displaced from the sediment, seems to apply to the Noce Stream, where Chironomidae were the dominant taxon in the drift collected at the same impacted stations during one hydropeaking wave (unpublished data). The differential ability of different taxa in using the hyporheic zone as a refuge is indicated also by the collection of early larval stages of Baetidae and Plecoptera in the hyporheic zone in this study, whereas the late larval stages of the same taxa where abundant in the drift.

Although the interplay among hydrological connectivity, water residence time, and substratum composition, generates the physical habitat matrix for the hyporheos of most rivers (Gibert, 1991; Boulton, 2007), much of the fine-scale patchiness of the hyporheos probably reflects a complex response to environmental parameters as well as biological interactions (Dole-Olivier and Marmonier, 1992; Strayer et al., 1997; Silver et al., 2002) such as competition and predation, although such interactions in streams are still poorly studied (Strayer, 1994). Predation by stream benthic macroinvertebrates on hyporheic meiofauna has received little study, although it has been shown to have an impact (Hakenkamp and Palmer, 2000), and the scarcity of specialized groundwater invertebrates from near-surface environments has been ascribed to the excessive predation from epigean predators (Marmonier, 1986). However, almost all the stygophile and stygoxene taxa collected in the hyporheic samples in this study were not predators, and the number of possible predators was so low that their influence in shaping the hyporheic communities can be considered negligible.

The two year sampling campaign allowed some interannual comparisons. The reasons of such temporal variability, represented by a decrease in the second year of the most abundant stygoxene taxa at the impacted stations, and of the most abundant stygobites at all stations, is difficult to determine. Dole-Olivier et al. (1997) describing the hyporheic zone acts as a patchy refugium, indicated how on a short spatial scale $(200,700$ and $900 \mathrm{~m}$ distance along a gravel bar), sampling stations were 
more or less active refugial zones, depending on hydrology (upwelling or downwelling), substratum stability and spate amplitude. The number of hydropeaking events on the Noce Stream varies from one year to the other, and as a consequence the physical and chemical characteristic of the hyporheic habitat can differ yearly, with consequent effects on the biota, whose abundance can fluctuate yearly.

This paper contributes to a better understanding of the implications of hydropeaking-induced disturbance for hyporheic invertebrates. Further investigation is needed to investigate the movement of invertebrates between the benthic and hyporheic zones, and to assess the intensity of clogging. Possible measures of mitigation of impacts induced by hydropeaking should in fact include the restoration of vertical linkages between the river and its shallow groundwater aquifers as a necessary step towards fully successful river rehabilitation.

Acknowledgements. This research is part of the project REPORT (Regulation of river discharges: guidelines for an eco-compatible management of the river dynamics), co-funded by the Adige River Authority. We would like to thank Dr. Fabio Stoch for providing taxonomic and ecological information on copepods. Excellent reviews by two anonymous referees and the Editor greatly improved the presentation of the manuscript.

\section{References}

Anderson N.H. and Cummins K.W., 1979. Influences of diet on life histories of aquatic insects. J. Fish. Res. Board Can., 36, 335-342.

Anselmetti F.S., Bühler R., Finger D., Girardclos S., Lancini A., Rellstab C. and Sturm M., 2007. Effects of Alpine hydropower dams on particle transport and lacustrine sedimentation. Aquat. Sci., 69, 179-198.

Autorità di Bacino dell'Adige, 2003. Quaderno 3. Progetto pilota per la redazione di un piano stralcio territoriale: il bacino dell'Avisio, Quaderni del Piano di Bacino a cura di Marcello Vittorini, $118 \mathrm{p}$.

Baumann P. and Meile T., 2004. Makrozoobenthos und Hydraulik in ausgewählten Querprofilen der Rhone. Wasser Energie Luft, 96, 320-325.

Blaschke A.P., Steiner K.-H., Schmalfuss R., Gutknecht D. and Sengschmitt D., 2003. Clogging processes in hyporheic interstices of an impounded river, the Danube at Vienna, Austria. Internat. Rev. Hydrobiol., 88, 397-413.

Bo T., Fenoglio S., Malacarne G., Pessino M. and Sgariboldi F., 2007. Effects of clogging on stream macroinvertebrates: An experimental approach. Limnologica, 37, 186-192.

Boon P.J., 1993. Distribution, abundance and development of Trichoptera larvae in the River North Tyne following the commencement of hydroelectric power generation. Reg. Rivers Res. Manage., 8, 211-224.

Boulton A.J., 2000. The subsurface macrofauna. In: Jones J. and Mulholland P. (eds.), Streams and Ground Waters, Academic Press, New York, 337-361.
Boulton A.J., 2001. Twixt two worlds: Taxonomic and functional biodiversity at the surface water/groundwater interface. Rec. West. Aust. Mus., 64 (Suppl.), 1-13.

Boulton A.J., 2007. Hyporheic rehabilitation in rivers: restoring vertical connectivity. Freshwater Biol., 52, 632-650.

Boulton A.J. and Stanley E.H., 1995. Hyporheic processes during flooding and drying in a Sonoran Desert stream. II. Faunal dynamics. Arch. Hydrobiol., 134, 27-52.

Boulton A.J., Findlay S., Marmonier P., Stanley E. and Valett H.M., 1998. The functional significance of the hyporheic zone in streams and rivers. Annu. Rev. Ecol. Syst., 29, 59-81.

Brittain J.E. and Eikeland T.J., 1988. Invertebrate drift. A review. Hydrobiologia, 166, 77-93.

Brunke M., 1999. Colmation and depth filtration within streambeds: retention of particles in hyporheic interstices. Int. Rev. Hydrobiol., 84, 99-117.

Brunke M. and Gonser T., 1997. The ecological significance of exchange processes between rivers and groundwater. Freshwater Biol., 37, 1-33.

Bruno M.C., Maiolini B., Silveri L., Carolli M. and Kerschbaumer G., 2008. Alterations of natural flow in field and flume conditions, Proceedings of the 4th ECRR (European Center for River Restoration) International Conference for River Restoration, Venice, 16-21 June 2008, Book of abstracts, p. 36.

Bunn S.E. and Arthington A.H., 2002. Basic principles and ecological consequences of altered flow regimes for aquatic biodiversity. Environ. Manage., 30, 492-507.

Caissie D., 2006. The thermal regime of rivers: a review. Freshwater Biol., 51, 1389-1406.

Campaioli S., Ghetti P.F., Minelli A. and Ruffo S., 1994. Manuale per il riconoscimento dei macroinvertebrati delle acque dolci italiane, Vol. I, Provincia Autonoma di Trento, $357 \mathrm{p}$.

Campaioli S., Ghetti P.F., Minelli A. and Ruffo S., 1999. Manuale per il riconoscimento dei macroinvertebrati delle acque dolci italiane, Vol. II, Provincia Autonoma di Trento, $127 \mathrm{p}$.

Carolli M., Maiolini B., Bruno M.C., Silveri L. and Siviglia A., 2009. Thermopeaking in an hydropower impacted Alpine catchment, Proceedings of the 4th ECRR (European Center for River Restoration) International Conference for River Restoration, Venice, 16-21 June 2008, 789-796.

Céréghino R. and Lavandier P., 1998a. Influence of hypolimnetic hydropeaking on the distribution and population dynamics of Ephemeroptera in a mountain stream. Freshwat. Biol., 40, 385-399.

Céréghino R. and Lavandier P., 1998b. Influence of hydropeaking on the distribution and larval development of the Plecoptera from a mountain stream. Reg. Rivers Res. Manage., 14, 297-309.

Céréghino R., Cugny P. and Lavandier P., 2002. Influence of intermittent hydropeaking on the longitudinal zonation patterns of benthic invertebrates in a mountain stream. Int. Rev. Hydrobiol., 87, 47-60.

Céréghino R., Legalle M. and Lavandier P., 2004. Drift and benthic population structure of the mayfly Rhithrogena semicolorata (Heptageniidae) under natural and hydropeaking conditions. Hydrobiologia, 519, 127-133.

Claret C., Marmonier P., Dole-Olivier M.-J., Creuzé Des Châtelliers M., Boulton A.J. and Castella E., 1999. 
A functional classification of interstitial invertebrates: supplementing measures of biodiversity using species traits and habitat affinities. Arch. Hydrobiol., 145, 385-403.

Clarke K.R., 1993. Non-parametric multivariate analysis of changes in community structure. Aust. J. Ecol., 18, 117143.

Cobb D.G., Galloway T.D. and Flannagan J.F., 1992. Effects of discharge and substrate stability on density and species composition of stream insects. Can. J. Fish. Aquat. Sci., 49, 1788-1795.

Crisp D.T. and Robson S., 1979. Some effects of discharge upon the transport of animals and peat in a north Pennine headstream. J. Appl. Ecol., 16, 721-736.

Cummins K.W., 1962. An evaluation of some techniques for the collection and analysis of benthic samples with special emphasis on lotic waters. Am. Midl. Nat., 67, 477-504.

Cunningham A.B., Anderson C.J. and Bouwer H., 1987. Effects of sediment-laden flow on channel bed clogging. J. Irrig. Drain. E.-ASCE, 113, 106-118.

Di Lorenzo T., De Laurentiis P. and Galassi D.M.P., 2003. L'inferenza biologica nella valutazione del grado di protezione naturale di sorgenti carsiche captate. Thal. Sal., 26, 241-248.

Diplas P. and Parker G., 1992. Deposition and removal of fines in gravel-bed streams. In: Billi P., Hey R.D., Thorne C.R. and Tacconi P. (eds.), Dynamics of Gravel-Bed Rivers, John Wiley and Sons Ltd, New York, 313-329.

Dole-Olivier M.J., 1998. Surface water-groundwater exchanges in three dimensions on a backwater of the Rhône River. Freshwat. Biol., 40, 93-109.

Dole-Olivier M.J. and Marmonier P., 1992. Patch distribution of interstitial communities: prevailing factors. Freshwat. Biol., 27, 177-191.

Dole-Olivier M.J., Marmonier P. and Beffy J.L., 1997. Response of invertebrates to lotic disturbance: is the hyporheic zone a patchy refugium? Freshwat. Biol., 37, 257-276.

Dufrêne M. and Legendre P., 1997. Species assemblages and indicator species: the need for a flexible asymmetrical approach. Ecol. Monogr., 67, 345-366.

Dussart B.H., 1967. Les Copépodes des eaux souterraines littorales et continentales d'Europe occidentale. Tome I: Calanoïdes et Harpacticoïdes, N. Boubee et Cie., Paris, $500 \mathrm{p}$.

Dussart B.H., 1969. Les Copépodes des eaux continentales d'Europe occidentale. Tome II : Cyclopoïdes et Biologie, N. Boubée et Cie, Paris, 292 p.

Fette M., Weber C., Peter A. and Wehrli B., 2007. Hydropower production and river rehabilitation: A case study on an alpine river. Environ. Model. Assess., 12, 257-267.

Fochetti R., Ravizza C.A. and Tierno De Figueroa J.M., 2009. Plecoptera, Vol. 43: Fauna d'Italia, Calderini, Bologna, $536 \mathrm{p}$.

Fowler R.T. and Death R.G., 2001. The effect of environmental stability on hyporheic community structure. Hydrobiologia, 445, 85-95.

Fowler R.T. and Scarsbrook M.E., 2002. Influence of hydrologic exchange patterns on water chemistry and hyporheic invertebrate communities in three gravel-bed rivers. New Zeal. J. Mar. Fresh., 36, 471-482.

Friedl G., Teodoru C. and Wehrli B., 2004. Is the Iron Gate I reservoir on the Danube River a sink for dissolved silica? Biogeochemistry, 68, 21-32.
Gayraud S. and Philippe M., 2001. Does subsurface interstitial space influence general characteristics and features and morphological traits of benthic macroinvertebrate communities in streams? Arch. Hydrobiol., 151, 667-686.

Gayraud S., Philippe M. and Maridet L., 2000. The response of benthic macroinvertebrates to artificial disturbance: drift or vertical movement in the gravel bed of two Sub-Alpine streams? Arch. Hydrobiol., 147, 431-446.

Gibbins C.N., Vericat D., Batalla R.J. and Gomez C.M., 2007a. Shaking and moving: low rates of sediment transport trigger mass drift of stream invertebrates. Can. J. Fish. Aquat. Sci., 64, 1-5.

Gibbins C.N., Vericat D. and Batalla R.J., 2007b. When is stream invertebrate drift catastrophic? The role of hydraulics and sediment transport in initiating drift during flood events. Freshwat. Biol., 52, 2369-2384.

Gibert J., 1991. Groundwater systems and their boundaries: Conceptual framework and prospects in groundwater ecology. Verh. Internat. Verein. Limnol., 24, 1605-1608.

Gibert J., Dole-Olivier M.-J., Marmonier P. and Vervier P., 1990. Surface water-groundwater ecotones. In: Naiman R.J.H. and Décamps H. (eds.), The ecology and management of aquatic-terrestrial ecotones, UNESCO and The Parthenon Publishing Group, London, England, 199-225.

Gibert J., Stanford J., Dole-Olivier M.-J. and Ward J.V., 1994. Basic attributes of ground water ecosystems and prospects for research. In: Gibert J., Danielopol D.L. and Stanford J. (eds.), Ground Water Ecology, Academic Press, San Diego, $7-40$.

Gore J.A., Nestler J.M. and Layzer J.B., 1989. Instream flow predictions and management options for biota affected by peakingpower hydroelectric operations. Reg. Rivers Res. Manage., 3, 35-48.

Gore J.A., Niemada S., Resh V.H. and Statzner B., 1994. Near substrate hydraulic conditions under artificial floods from peaking hydropower operations: a preliminary analysis of disturbance intensity and duration. Reg. Rivers Res. Manage., 9, 15-34.

Grimm N.B., Valett H.M., Stanley E.H. and Fisher S.G., 1991. Contribution of the hyporheic zone to stability of an aridland stream. Verh. Int. Ver. Theoret. Angew. Limnol., 24, 1595-1599.

Hakenkamp C.C. and Palmer M.A., 2000. The ecology of hyporheic meiofauna. In: Jones J.B. and Mulholland P.J. (eds.), Streams and Ground Waters, Academic Press, San Diego, 307-336.

Hancock P., 2002. Human impacts on the stream-groundwater exchange zone. Environ. Manage., 29, 761-781.

Hill M.O. and Gauch H.G., 1980. Detrended correspondence analysis: an improved ordination technique. Vegetatio, 42, 47-58.

Humborg C., Conley D.J., Rahm L., Wulff F., Cociasu A. and Ittekkot V., 2000. Silicon retention in river basins: Farreaching effects on biogeochemistry and aquatic food webs in coastal marine environments. Ambio, 29, 45-50.

Imbert J.B. and Perry J.A., 2000. Drift and benthic invertebrate responses to stepwise and abrupt increases in non-scouring flow. Hydrobiologia, 436, 191-208.

Irvine J.R., 1985. Effects of successive flow perturbations on stream invertebrates. Can. J. Fish. Aquat. Sci., 42, 1922-1927. 
Jakob C., Robinson C.T. and Uehlinger U., 2003. Longitudinal effects of experimental floods on stream benthos downstream from a large dam. Aquat. Sci., 65, 223-231.

Jaun L., Finger D., Zeh M., Schurter M. and West A., 2007. Effects of upstream hydropower operation and oligotrophication on the light regime of a turbid peri-alpine lake. Aquat. Sci., 69, 212-226.

Karaytug S., 1999. Copepoda: Cyclopoida. Genera Paracyclops, Ochridacyclops and Key to the Eucyclopinae - Guides to the Identification of the Microinvertebrates of the Continental Waters of the World, Dumont H.J.F. (ed.), SPB Academic Publishing, The Netherlands, The Hague, 14, 1-224.

Lancaster J. and Belyea L.R., 1997. Nested hierarchies and scaledependence of flow refugium use. J. N. Am. Benthol. Soc., 16, 221-238.

Liebig H., Céréghino R., Lim P., Belaud A. and Lek S., 1999. Impact of hydropeaking on the abundance of juvenile brown trout in a Pyrenean stream. Arch. Hydrobiol., 144, 439-454.

Lock K. and Goethals P.L.M., 2008. Distribution and ecology of the stoneflies (Plecoptera) of Flanders (Belgium). Ann. Limnol. - Int. J. Lim., 44, 203-213.

Loizeau J.L. and Dominik J., 2000. Evolution of the upper Rhone River discharge and suspended sediment load during the last 80 years and some implications for Lake Geneva. Aquat. Sci., 62, 54-67.

Marchant R., 1988. Vertical distribution of benthic invertebrates in the bed of the Thomson River, Victoria. Aust. J. Mar. Fresh. Res., 39, 775-784.

Maridet L., Philippe M., Wasson J.G. and Mathieu J., 1996. Spatial and temporal distribution of macroinvertebrates and trophic variables within the bed sediment of three streams differing by their morphology and riparian vegetation. Arch. Hydrobiol., 136, 41-64.

Marmonier P., 1986. Spatial distribution and temporal evolution of Gammarus fossarum, Niphargus sp. (Amphipoda) and Proasellus slavus (Isopoda) in the Seebach sediments (Lunz, Austria). Jahresber. Biol. Stn. Lunz, 8, 40-54.

Marmonier P., Vervier P., Gibert J. and Dole-Olivier M.-J., 1993. Biodiversity in ground waters. TREE, 8, 392-395.

McCune B. and Mefford M.J., 1999. Multivariate Analysis of Ecological Data Version 4.20, MjM Software, Gleneden Beach, Oregon, USA.

Moog O., 1993. Quantification of daily peak hydropower effects on aquatic fauna and management to minimize environmental impacts. Regul. River., 8, 5-14.

Palmer M.A., Bely A.E. and Berg K.E., 1992. Response of invertebrates to lotic disturbance: a test of the hyporheic refuge hypothesis. Oecologia, 89, 182-194.

Palmer M.A., Arensburger P., Martin A.P. and Denman D.W., 1996. Disturbance and patch-specific responses: the interactive effects of woody debris and floods on lotic invertebrates. Oecologia, 105, 247-257.

PASCALIS, 2001. Protocols for the ASsessment and Conservation of Aquatic Life In the Subsurface, Sampling Manual for the Assessment of Regional Groundwater Biodiversity, Malard F. (ed.). Available at http://serv-umr5023. univ-lyon1.fr/ pascalis/results/samplingmanual.html.

Pesce G.L. and Galassi D.M.P., 1987. New or rare species of Diacyclops Kiefer, 1927 (Copepoda, Cyclopoida) from different groundwater habitats in Italy. Hydrobiologia, 148, 103-144.
Picazo J. and Ocana A., 1991. Distribution of nematode orders in a river subjected to pollution: the Monachil River (Granada, Spain). Limnetica, 7, 11-24.

Pielou E.C., 1969. An Introduction to Mathematical Ecology, Wiley, New York, 286 p.

Preece R.M. and Jones H.A., 2002. The effect of Keepit Dam on the temperature regime of the Namoi River, Australia. River Res. Appl., 18, 397-414.

PRIMER-E Ltd., 2006. PRIMER 6: Plymouth Routines In Multivariate Ecological Research.

Provincia Autonoma di Trento, 2006. Piano Generale di Utilizzazione delle Acque Pubbliche. http://www.pguap. provincia.tn.it/PGUAP/.

Robertson A.L., Lancaster J. and Hildrew A.G., 1995. Stream hydraulics and the distribution of microcrustacea - a role for refugia. Freshwat. Biol., 33, 469-484.

Robertson A.L., Lancaster J., Belyea L.R. and Hildrew A.G., 1997. Hydraulic habitat and the assemblage structure of stream benthic microcrustacea. J. N. Am. Benthol. Soc., 16, 562-575.

Sanders H., 1968. Marine benthic diversity: a comparative study. Am. Nat., 102, 243-282.

Schälchli U., 1992. The clogging of coarse gravel river beds by fine sediment. Hydrobiologia, 235/236, 189-197.

Schmid P.E. and Schmid-Araya J.M., 1997. Predation on meiobenthic assemblages: resource use of a tanypod guild (Chironomidae, Diptera) in a gravel stream. Freshwat. Biol., $38,67-91$.

Schmid-Araya J.M. and Schmid P.E., 2000. Trophic relationships: integrating meiofauna into a realistic benthic food web. Freshwat. Biol., 44, 149-163.

Schwoerbel J., 1962. Hyporheische Besiedlung geröllführender Hochgebirsbäche mit gewebter Stromsohle. Die Naturwissenschaften, 49, 67.

Silver P., Palmer M.A., Swan C.M. and Wooster D., 2002. The small scale ecology of freshwater meiofauna. In: Rundle S.D., Robertson A.L. and Schmid-Araya J.M. (eds.), Freshwater Meiofauna: Biology and Ecology, Backhuys, Leiden, The Netherlands, 217-239.

Siviglia A., Salvaro M., Zolezzi G., Carolli M., Bruno M.C. and Maiolini B., 2009. Field observations of thermopeaking in Alpine streams, Proceedings of the 7th International Symposium on Ecohydraulics, Concepcion, Chile, ISE-1A4-FRB3.

Stanford J.A. and Gaufin A.R., 1974. Hyporheic communities of two Montana rivers. Science, 185, 700-702.

StatSoft Inc., 2008. STATISTICA (data analysis software system), version 8.1. www.stasoft.com.

Stoch F., 1998. Moraria alpina n. sp. and redescription of Moraria radovnae Brancelj 1988, new rank, from Italian and Slovenian Alps (Crustacea, Copepoda, Harpacticoida). St. Trent. Sc. Nat. - Acta Biologica, 73, 135-145.

Stoch F., 2000-2006. CKmap for Windows, Version 5.3, Ministry for Environment, Territory and Sea, Nature Protection Directorate. http://ckmap.faunaitalia.it.

Strayer D.L., 1994. Limits to biological sitribution. In: Gibert J., Danielopol D.L. and Stanford J. (eds.), Ground Water Ecology, Academic Press, San Diego, 287-310.

Strayer D.L., May S.E., Nielsen P., Wolheim W. and Hausam S., 1997. Oxygen, organic matter, and sediment granulometry as controls on hyporheic animal communities. Arch. Hydrobiol., 140, 131-144. 
Townsend C.R. and Hildrew A.G., 1994. Species traits in relation to a habitat templet for river systems. Freshwat. Biol., 31, 265-276.

Townsend C.R., Scarsbrook M.R. and Doledec S., 1997. The intermediate disturbance hypothesis, refugia and biodiversity in streams. Limnol. Oceanogr., 42, 938-949.

Troelstrup N.H. and Hergenrader G.L., 1990. Effect of hydropower peaking flow fluctuations on community structure and feeding guilds of invertebrates colonizing artificial substrates in a large impounded river. Hydrobiologia, 199, 217-228.

Ward J.V., 1992. Aquatic Insect Ecology. Vol. 1: Biology and Habitat, Wiley, New York, 438 p.

Ward J.V., 1994. The structure and dynamics of lotic ecosystems. In: Margalef R. (ed.), Limnology Now: A Paradigm of Planetary Problems, Elsevier Science, Amsterdam, 195-218.

Williams D.D., 1984. The hyporheic zone as a habitat for aquatic insects and associated arthropods. In: Resh V.H. and Rosenberg D.M. (eds.), The ecology of aquatic insects, Praeger, New York, 430-455; Chapman \& Hall, London, 195-223.

Williams D.D. and Hynes H.B.N., 1974. The occurrence of benthos deep in the substratum of a stream. Freshwat. Biol., 4, 233-256.

Wong M. and Parker G., 2006. One-dimensional modeling of bed evolution in a gravel bed river subject to a cycled flood hydrograph. J. Geophys. Res., 111, F03018.

Wüest A., Moosmann L. and Friedl G., 2002. Alpine hydroelectric power plants and their "long-range effects" on downstream waters. EAWAG news, 55e, 18-20.

Zolezzi G., Bellin A., Bruno M.C., Maiolini B. and Siviglia A., to appear. Assessing hydrological alterations at multiple temporal scales: Adige River, Italy. Water Resour. Res.

Zullini A., 1976. Nematodes as indicators of river pollution. Nematol. Medit., 4, 13-22. 